\title{
The relationship between the systemic inflammatory response, tumour proliferative activity, T-lymphocytic infiltration and COX-2 expression and survival in patients with transitional cell carcinoma of the urinary bladder
}

\author{
M Hilmy,', R Campbell', JMS Bartlett', A-M McNicol'2, MA Underwood' and DC McMillan' \\ 'Department of Surgery, Royal Infirmary University, Glasgow G3I 2ER, UK and '2Department of Pathology, Royal Infirmary University, \\ Glasgow G3I 2ER, UK
}

\begin{abstract}
The relationship between the systemic inflammatory response, tumour proliferative activity, T-lymphocytic infiltration, and COX-2 expression and survival was examined in patients with transitional cell carcinoma of the urinary bladder $(n=103)$. Sixty-one patients had superficial disease and 42 patients had invasive disease. Cancer-specific survival was shorter in those patients with invasive compared with superficial bladder cancer $(P<0.00 I)$. On univariate analysis, stratified by stage, increased Ki-67 labelling index $(P<0.05)$, increased COX-2 expression $(P<0.05)$, C-reactive protein $(P<0.05)$ and adjuvant therapy $(P<0.0 \mathrm{I})$ were associated with poorer cancer-specific survival. On multivariate analysis of these significant factors, stratified by stage, only $C$-reactive protein ( HR 2.89, 95\% Cl I.42-5.9I, $P=0.004)$ and adjuvant therapy $(\mathrm{HR} 0.29,95 \% \mathrm{Cl} 0.14-0.62, P=0.00 \mathrm{I})$ were independently associated with poorer cancer-specific survival. These results would suggest that tumour-based factors such as grade, COX-2 expression or T-lymphocytic infiltration are subordinate to systemic factors such as C-reactive protein in determining survival in patients with transitional cell carcinoma of the urinary bladder.
\end{abstract}

British Journal of Cancer (2006) 95, 1234-1238. doi:I0.1038/sj.bjc.66034I5 www.bjcancer.com

Published online 3 October 2006

(c) 2006 Cancer Research UK

Keywords: bladder cancer; Ki-67; C-reactive protein; T-lymphocytes; COX-2; survival

Bladder cancer is the fourth most common malignancy in the Western World. In the UK, there are 12500 new cases each year and 5000 deaths annually (CancerStats, 2002). The mortality from transitional cell carcinoma of the urinary bladder increases significantly with the progression of superficial to invasive disease. One of the common prognostic marker in clinical use is tumour grade, which is subject to considerable intra- and interobserver variation. Therefore, monitoring the possible progression of superficial transitional cell carcinomas constitutes a significant proportion of the general urological consultants' workload.

It is now recognised that disease progression is dependent on a complex interaction of the tumour and the host inflammatory response (Balkwill and Mantovani, 2001; Coussens and Werb 2002; Vakkila and Lotze 2004). Recently, the systemic inflammatory response, as evidenced by elevated circulating concentrations of C-reactive protein, has been shown to be independently associated with poorer survival in patients with advanced cancer (O'Gorman et al, 2000; Forrest et al, 2003; Maltoni et al, 2005). There is also evidence that C-reactive protein has independent prognostic value in primary operable cancer (Ikeda et al, 2003; McMillan et al, 2003; Jamieson et al, 2005; Crumley et al, 2006; Lamb et al, 2006).

*Correspondence: M Hilmy; E-mail: m.hilmy@doctors.net.uk Revised 22 August 2006; accepted 7 September 2006; published online 3 October 2006
Therefore, it would appear that the systemic inflammatory response is of considerable importance in the relationship between the tumour, the host and outcome in patients with cancer. Recently, we have reported that an elevated C-reactive protein was associated with poor cancer-specific survival in patients with bladder cancer independent of tumour stage and grade (Hilmy et al, 2005).

The basis of the independent relationship between an elevated $\mathrm{C}$-reactive protein concentration and poor survival in cancer is not clear. There are a number of possible explanations. Firstly, that an elevated C-reactive protein identifies tumours capable of producing significant amounts of proinflammatory cytokines, in particular interleukin-6 (Kinoshita et al, 1999; McKeown et al, 2004) and therefore with the potential for more rapid growth of tumour cells (Jee et al, 2001; Trikha et al, 2003). Alternatively, Creactive protein could directly impair immune function (Maccio et al, 1998; Du Clos and Mold, 2004; Canna et al, 2005) allowing unrestrained tumour growth and dissemination.

Precise localisation of pro-inflammatory cytokines such as interleukin-6 to tumour cells or inflammatory cells within the tumour, particularly in paraffin-embedded tissues, remains problematical (Canna et al, 2005). However, tumour proliferative activity has been reliably assessed using the Ki-67 labelling index in a variety of solid tumours, including bladder cancer (Blanchet et al, 2001; Habuchi et al, 2005). Also, infiltration of tumours with 
T-lymphocytes has been reliably demonstrated in a variety of solid tumours, including bladder cancer (Stavropoulos et al, 1998; Bevers et al, 2004).

Central to the local inflammatory response is cyclooxygenase-2 and increased expression has been shown to be associated with poor survival in a number of common solid tumours (Dannenberg et al, 2001; Dannenberg and Subbaramaiah, 2003) including bladder cancer (Shirahama et al, 2001; Shariat et al, 2003).

The aim of the present study was therefore to examine the relationship between the systemic inflammatory response (Creactive protein), tumour proliferative activity (Ki-67), T-lymphocyte $(\mathrm{CD} 4+, \mathrm{CD} 8+)$ infiltration, and COX-2 expression and cancer-specific survival in patients with transitional cell carcinoma of the bladder.

\section{METHODS}

\section{Patients}

A cross-sectional retrospective study of patients with biopsyproven transitional cell carcinoma and with a measurement of C-reactive protein before transurethral resection of bladder tumour in Glasgow Royal Infirmary between 1992 and 2001 was carried out. Tumours were grouped according to whether they were superficial (pTa, pT1 and CIS) or muscle invasive (pT2pT4). However, patients with pT1G3 were considered as muscle invasive tumours as they are recognised to have a significantly higher progression rate (Manoharan and Soloway, 2005). At this time, no patient showed clinical evidence of infection, or other inflammatory conditions. Tumour stage was assessed using the 1997 AJCC/UICC TNM classification (Sobin and Wittekind, 1997), and tumour grade was performed according to the 1999 WHO grading system (Busch and Algaba, 2002).

Routine laboratory measurement of patient's serum for Creactive protein concentration was performed. The limit of detection of the assay was a C-reactive protein concentration lower than $5 \mathrm{mgl}^{-1}$. The coefficient of variation, over the range of measurement, was less than $5 \%$ as established by routine quality control procedures. C-reactive protein measurement of greater than $10 \mathrm{mg} \mathrm{l}^{-1}$ was considered to indicate the presence of systemic inflammatory response (O'Gorman et al, 2000).

The Research Ethics Committee of North Glasgow NHS Trust approved the study.

\section{Immunohistochemistry}

Blocks from the primary tumour were fixed in $10 \%$ buffered formalin in saline and embedded in paraffin wax. One representative block of tumour was selected for each patient. Serial individual sections $(4 \mu \mathrm{m})$ were cut and mounted on slides coated with aminopropyltriethoxysilane for the immuno-histochemistry of Ki$67, \mathrm{CD} 4+$ and CD8 + T-lymphocytes and COX-2 expression.

\section{Ki-67}

Sections were immunostained using a streptavidin biotin technique (Dako, Cambridgeshire, UK) as previously described (McNicol et al, 1997). The primary antibody for Ki-67 was mouse monoclonal antibody (Dako, Cambridgeshire, UK).

\section{CD4 + and CD8 + T-lymphocytes}

Sections were immunostained using the peroxidase-based Envision technique (Dako, Cambridgeshire, UK) as described previously (Bromwich et al, 2003). The primary antibody for CD4 was mouse monoclonal (Vector, Peterborough, UK) and that for CD8 was mouse monoclonal (Dako, Cambridgeshire, UK).

\section{COX-2}

Sections were immunostained using the biotinylated/streptavidin peroxidase complex technique (Dako, Cambridgeshire, UK) as previously described (Edwards et al, 2004). The primary antibody was human monoclonal antibody (Cayman Chemical Co., Annbor, Michigan, USA).

\section{Morphometry}

The percentages of Ki-67-reactive tumour cells were evaluated at $\times 400$ magnification by scoring a minimum of 1000 tumour cells in randomly selected fields (Ki-67 labelling index). Cases were counted by two observers and the highest score was chosen as the corresponding index.

Quantitative analysis of the lymphoid infiltrate was performed using point counting (Anderson and Dunnill, 1965) with a random sampling technique. With this method, the volume occupied by any given component (volume density) is expressed as a percentage of the total volume of the tissue. A 100-point ocular grid was used at $\times 400$ magnification and 30 fields were counted per case for CD4 + and CD8 + immunopositive cells. Only fields within the tumour (including cancer cell nests and surrounding tissue stroma) were counted. Any normal tissue on the slide was excluded from the analysis.

Semiquantitative analysis of the COX-2 expression was scored using a weighted histoscore method (Kirkegaard et al, 2006). Histoscores were calculated from the sum of $(1 \times \%$ cells staining weakly positive $)+(2 \times \%$ cell staining moderately positive $)$ $+(3 \times \%$ cells staining strongly positive $)$ with a maximum of 300 . The mean of the two observers' scores were used for the analysis as previously described (Edwards et al, 2004; Witton et al, 2004).

The observers ( $\mathrm{MH}$ and $\mathrm{RC}$ ) were blinded to the clinical outcome of the patient.

\section{Statistical analysis}

Data are presented as median and range. For the purpose of analysis, the tumour Ki-67 labelling index, CD4 + and CD8 + Tlymphocyte counts and COX-2 expression were grouped by tertiles. The relationships between these and other variables were analyzed using the Mantel-Haenszel $\left(\chi^{2}\right)$ test for trend and Spearman's rank correlation as appropriate.

Survival analysis was performed using the Cox proportional hazard model. Multivariate survival analysis was performed using stepwise backward procedure to derive a final model of the variables that had a significant independent relationship with survival. To remove a variable from the model, the corresponding $P$-value had to be greater than 0.10. Deaths up to 31 August 2005 have been included in the analysis. Analysis was performed using SPSS software (SPSS Inc., Chicago, IL, USA).

\section{RESULTS}

The characteristics of patients with bladder cancer $(n=103)$ that were grouped according to stage are shown in the Table 1. The majority of patients were male, over the age of 65 years, had superficial disease and were with elevated C-reactive protein concentration preoperatively. Patients with invasive bladder cancer were older $(P<0.01)$ and had higher grade tumours $(P<0.001)$, increased Ki-67 labelling index $(P<0.001)$, increased tumour expression of COX-2 $(P<0.001)$ compared with superficial disease. Also, patients with invasive disease had lower tumour infiltration of $\mathrm{CD} 4+(P<0.05)$ and $\mathrm{CD} 8+$ T-lymphocytes $(P<0.01)$ and had evidence of a systemic inflammatory response $(P<0.05)$. Patients with invasive bladder cancer received more additional therapy $(P<0.05)$. In total, 22 patients had additional therapy (seven cystectomy, 
nine radiotherapy and six bacillus of Calmette and Guerin (BCG)). Cancer-specific survival was shorter in those patients with invasive bladder cancer compared with superficial bladder cancer $(P<0.001)$.

The median follow-up of the survivors was 60 months. During the course of the study, 66 patients died, 42 patients of their cancer and 24 of intercurrent disease. On univariate analysis, stratified by stage, increased Ki-67 labelling index $(P<0.05)$, increased COX-2 expression $(P<0.05)$, C-reactive protein $(P<0.05)$ and no adjuvant therapy $(P<0.01)$ were associated with poorer cancer-specific survival (Table 2).

On multivariate analysis of these significant factors, stratified by stage, only C-reactive protein (HR 2.89, 95\% CI 1.42-5.91, $P=0.004)$ and no adjuvant therapy (HR $0.29,95 \%$ CI $(0.14-0.62$, $P=0.001)$ was independently associated with poorer cancerspecific survival. When $\mathrm{C}$-reactive protein was excluded from the multivariate analysis, stratified by stage, only Ki-67 labelling index (HR 1.56, 95\% CI $0.99-2.45, P=0.045$ ) and adjuvant therapy (HR $0.41,95 \%$ CI $0.19-0.86, P=0.019)$ were independently associated with poorer cancer-specific survival.

The inter-relationships between the clinicopathological characteristics are shown in Table 3. In all patients, tumour grade was directly associated with Ki-67 labelling index $(P<0.001)$, COX-2 expression $(P<0.001), \mathrm{CD} 4+(P<0.01)$ and $\mathrm{CD} 8+(P<0.001)$ T-lymphocytes, but not with $C$-reactive protein $(P=0.152)$. The Ki-67 labelling index was directly associated with COX-2 expression $(P<0.001), \mathrm{CD} 4+\quad(P<0.001)$ and $\mathrm{CD} 8+\quad(P<0.01)$ T-lymphocytes and, and also with $C$-reactive protein $(P=0.039)$.
The tumour COX-2 expression was directly associated with the tumour $\mathrm{CD} 4+(P<0.01)$ and $\mathrm{CD} 8+(P<0.05)$ T-lymphocytic infiltrate and weakly with $\mathrm{C}$-reactive protein $(P=0.068)$. The tumour $\mathrm{CD} 4+\mathrm{T}$-lymphocytic infiltrate was directly associated with CD8 $+(P<0.001)$ but not with $\mathrm{C}$-reactive protein $(P=0.556)$ The tumour CD8 + T-lymphocytic infiltrate was not associated with C-reactive protein $(P=0.892)$.

\section{DISCUSSION}

In the present study, tumour grade and Ki-67 labelling index were associated with increased tumour COX-2 expression and infiltration by $\mathrm{CD} 4+$ and $\mathrm{CD} 8+\mathrm{T}$-lymphocytes in patients with transitional cell carcinoma of the bladder. However, on univariate analysis, only increased $\mathrm{Ki}-67$ labelling index and COX-2 expression were significantly associated with poorer cancer-specific survival. However, neither of these tumour-based factors was independently significant when a marker of the systemic inflammatory response (C-reactive protein) was included in the survival analysis. Therefore, the present study examines, for the first time, the relationship between the preoperative systemic inflammatory response and tumour-based factors and suggests that the systemic inflammatory response is more closely related to outcome in patients with transitional cell carcinoma of the bladder.

These results are consistent with the superior prognostic value of C-reactive protein compared with tumour T-lymphocytic

Table I Relationship between tumour stage and clinicopathological characteristics in patients with bladder cancer

\begin{tabular}{|c|c|c|c|}
\hline & Superficial $(n=6 I)$ & Invasive $(n=42)$ & $P$-value \\
\hline Age group ( $\leqslant 65 />65$ years) & $30 / 31$ & $10 / 32$ & 0.010 \\
\hline Sex (male/female) & $44 / 17$ & $26 / 16$ & 0.277 \\
\hline \multicolumn{4}{|l|}{ Tumour grade } \\
\hline GI/G2/G3 & $26 / 32 / 3$ & $0 / 6 / 36$ & $<0.001$ \\
\hline Ki-67 (tertiles I, 2, 3) & $20 / 30 / 11$ & $5 / 14 / 23$ & $<0.001$ \\
\hline COX-2 (tertiles I, 2, 3) & $31 / 25 / 5$ & $4 / 9 / 29$ & $<0.001$ \\
\hline \multicolumn{4}{|l|}{ \% Tumour volume T-lymphocytes } \\
\hline CD4+ (tertiles I, 2, 3) & $25 / 21 / 15$ & $10 / 13 / 19$ & 0.022 \\
\hline CD8+ (tertiles I, 2, 3) & $26 / 21 / 14$ & $9 / 13 / 20$ & 0.005 \\
\hline C-reactive protein $\left(\leqslant 10 />10 \mathrm{mg}^{-1}\right)$ & $32 / 29$ & $13 / 29$ & 0.031 \\
\hline Adjuvant therapy (no/yes) & $53 / 8$ & $28 / 14$ & 0.014 \\
\hline Cancer-specific survival (months) & $109(94-125)^{a}$ & $41(24-58)^{a}$ & $<0.001$ \\
\hline
\end{tabular}

aMean $(95 \% \mathrm{Cl})$.

Table 2 Relationship between clinicopathological characteristics and cancer-specific survival, stratified by stage, in patients with bladder cancer; univariate survival analysis

\begin{tabular}{|c|c|c|c|}
\hline & Patients $(n=103)$ & Hazard ratio $(95 \% \mathrm{Cl})$ & $P$-value \\
\hline Age group ( $\leqslant 65 />65$ years) & $40 / 63$ & $1.52(0.76-3.02)$ & 0.234 \\
\hline Sex (male/female) & $70 / 33$ & $0.72(0.37-1.39)$ & 0.322 \\
\hline \multicolumn{4}{|l|}{ Tumour grade } \\
\hline G1/G2/G3 & $26 / 38 / 39$ & $1.18(0.57-2.48)$ & 0.653 \\
\hline Ki-67 (tertiles I, 2, 3) & $34(2-78)^{a}$ & $1.73(1.1 \mid-2.72)$ & 0.017 \\
\hline coX-2 (tertiles I, 2, 3) & $200(100-300)^{\mathrm{a}}$ & $1.95(1.11-3.42)$ & 0.020 \\
\hline \multicolumn{4}{|l|}{ \% Tumour volume T-lymphocytes } \\
\hline CD4+ (tertiles I, 2, 3) & $2.70(0-12.30)^{a}$ & $1.26(0.84-1.88)$ & 0.260 \\
\hline CD8+ (tertiles I, 2, 3) & $2.20(0.16-10.20)^{a}$ & $1.27(0.87-1.86)$ & 0.221 \\
\hline C-reactive protein $\left(\leqslant 10 />10 \mathrm{mg}^{-1}\right)$ & $45 / 58$ & $2.36(1.17-4.74)$ & 0.016 \\
\hline Adjuvant therapy (no/yes) & $81 / 22$ & $0.36(0.17-1.75)$ & 0.006 \\
\hline
\end{tabular}

a Median (range) 
Table 3 Inter-relationships between the clinicopathological characteristics in patients with bladder cancer

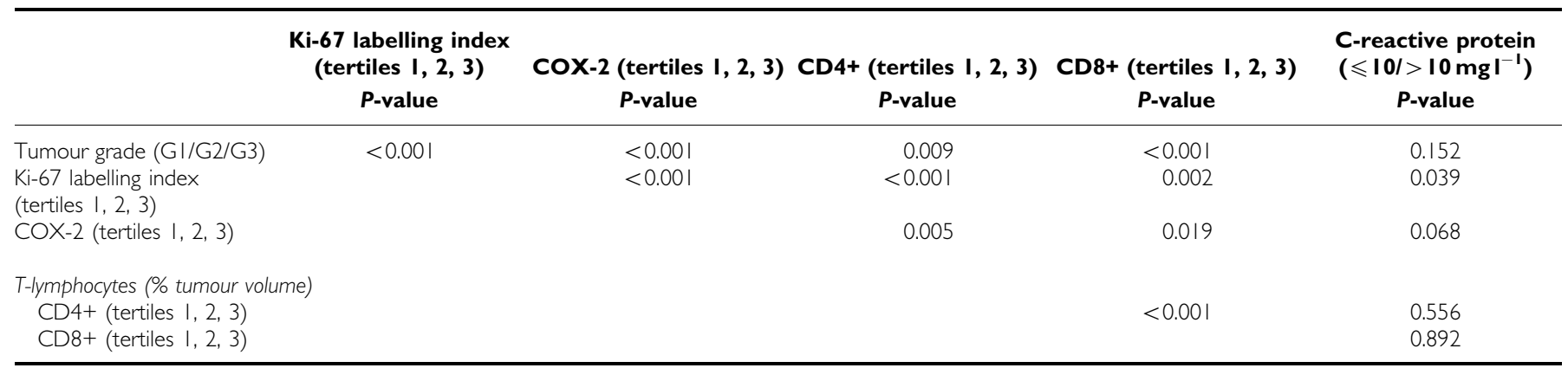

infiltration in patients with primary operable colorectal cancer (Canna et al, 2005). One possible explanation is that C-reactive protein can be measured with greater accuracy and precision than tumour-based factors. Alternatively, it may be that C-reactive protein plays a more pivotal role in the tumour-host relationship. C-reactive protein is recognised to be an activator of innate immunity and a modulator of adaptive immunity (Du Clos and Mold, 2004) and its elevation is a precursor to progressive involuntary loss of weight and lean tissue, which are believed to be key factors in determining cancer survival (McMillan et al, 1998; Kotler, 2000).

The results of the present study do not exclude nonmalignant causes of an elevated C-reactive protein in patients with transitional cell carcinoma of the urinary bladder. However, it is of interest that C-reactive protein concentrations above the threshold used in the present study $\left(>10 \mathrm{mgl}^{-1}\right)$ are rare $(<5 \%)$ in the general elderly population in the West of Scotland (O'Reilly et al, 2006).

Therefore, it may be that an elevated C-reactive protein concentration would be a useful marker of the host inflammatory response, in addition to other risk factors, to stratify patients into specific follow-up regimes. If further prospective studies show this to be the case, it may therefore reduce the workload and anxiety in those patients with superficial bladder cancer in whom continuous follow-up is the norm despite less than $50 \%$ probability of tumour recurrence.

These results are consistent with previous studies that have examined the prognostic value of Ki-67 labelling index (Habuchi et al, 2005). Similarly, in the largest studies, tumour COX-2 expression has been shown to be significantly associated

\section{REFERENCES}

Alexandroff AB, Jackson AM, O’Donnell MA, James K (1999) BCG immunotherapy of bladder cancer: 20 years on. Lancet 353: 1689-1694

Anderson JA, Dunnill MS (1965) Observations on the estimation of the quantity of emphysema in the lungs by the point-sampling method. Thorax 20: $462-466$

Balkwill F, Mantovani A (2001) Inflammation and cancer: back to Virchow? Lancet 357: $539-545$

Bevers RF, Kurth KH, Schamhart DH (2004) Role of urothelial cells in BCG immunotherapy for superficial bladder cancer. Br J Cancer 91: 607-612

Blanchet P, Droupy S, Eschwege P, Viellefond A, Paradis V, Pichon MF, Jardin A, Benoit G (2001) Prospective evaluation of Ki-67 labelling in predicting the recurrence and progression of superficial bladder transitional cell carcinoma. Eur Urol 40: $169-175$

Bromwich EJ, McArdle PA, Canna K, McMillan DC, McNicol AM, Brown M, Aitchison M (2003) The relationship between T-lymphocyte infiltration, stage, tumour grade and survival in patients undergoing curative surgery for renal cell cancer. Br J Cancer 89: 1906-1908

Busch C, Algaba F (2002) The WHO/ISUP 1998 and WHO 1999 systems for malignancy grading of bladder cancer: scientific foundation and with survival on univariate but not multivariate analyses (Shirahama et al, 2001; Shariat et al, 2003). However, to our knowledge there have been no studies that have examined the relationship between tumour $\mathrm{CD} 4+$ and $\mathrm{CD} 8+$ T-lymphocytic infiltration and cancer-specific survival in patients with bladder cancer.

The results of the present study are consistent with the concept that there is an active immune response to tumour cell proliferation in these patients and that proliferative activity and COX-2 expression may play a role in disease progression. It is therefore of interest that intravesical treatment of superficial carcinoma with BCG vaccine appears to reduce both disease recurrence and progression (Lamm, 2000). It may be that those patients with a high Ki-67 labelling index and COX-2 expression and a marked lymphocytic infiltration will have a better response to BCG (Alexandroff et al, 1999; O'Donnell, 2005).

In summary, the results of the present study shows that, in addition to grade and Ki-67 labelling index, both local (tumour COX-2 expression) and systemic (C-reactive protein) markers of the inflammatory response were associated with poor cancerspecific survival. However, on multivariate analysis only C-reactive protein had independent prognostic value in patients with transitional cell carcinoma of the urinary bladder.

\section{ACKNOWLEDGEMENTS}

This work was kindly supported by the Chief Scientist Office, Scottish Home and Health Department.

translation to one another and previous systems. Virchows Arch 441: $105-108$

CancerStats (2002) www.cancerresearchuk.org

Canna K, McArdle PA, McMillan DC, McNicol AM, Smith GW, McKee RF, McArdle CS (2005) The relationship between tumour T-lymphocyte infiltration, the systemic inflammatory response and survival in patients undergoing curative resection for colorectal cancer. $\mathrm{Br} \mathrm{J}$ Cancer 92: $651-654$

Coussens LM, Werb Z (2002) Inflammation and cancer. Nature 420: $860-867$

Crumley AB, McMillan DC, McKernan M, Going JJ, Shearer CJ, Stuart RC (2006) An elevated C-reactive protein concentration, prior to surgery, predicts poor cancer-specific survival in patients undergoing resection for gastro-oesophageal cancer. Br J Cancer 94: 1568-1571

Dannenberg AJ, Altorki NK, Boyle JO, Dang C, Howe LR, Weksler BB, Subbaramaiah K (2001) Cyclo-oxygenase 2: a pharmacological target for the prevention of cancer. Lancet Oncol 2: 544-551

Dannenberg AJ, Subbaramaiah K (2003) Targeting cyclooxygenase-2 in human neoplasia: rationale and promise. Cancer Cell 4: 431-436 
Du Clos TW, Mold C (2004) C-reactive protein: an activator of innate immunity and a modulator of adaptive immunity. Immunol Res 30: $261-277$

Edwards J, Mukherjee R, Munro AF, Wells AC, Almushatat A, Bartlett JMS (2004) HER2 and COX-2 expression in human prostate cancer. Eur J Cancer 40: $50-55$

Forrest LM, McMillan DC, McArdle CS, Angerson WJ, Dunlop DJ (2003) Evaluation of cumulative prognostic scores based on the systemic inflammatory response in patients with inoperable non-small-cell lung cancer. Br J Cancer 89: $1028-1030$

Habuchi T, Marberger M, Droller MJ, Hemstreet III GP, Grossman HB, Schalken JA, Schmitz-Drager BJ, Murphy WM, Bono AV, Goebell P, Getzenberg RH, Hautmann SH, Messing E, Fradet Y, Lokeshwar VB (2005) Prognostic markers for bladder cancer: International Consensus Panel on bladder tumor markers. Urology 66(6 Suppl 1): 64-74

Hilmy M, Bartlett JM, Underwood MA, McMillan DC (2005) The relationship between the systemic inflammatory response and survival in patients with transitional cell carcinoma of the urinary bladder. $\mathrm{Br} J$ Cancer 92: 625-627

Ikeda M, Natsugoe S, Ueno S, Baba M, Aikou T (2003) Significant host- and tumour-related factors for predicting prognosis in patients with oesophageal carcinoma. Ann Surg 238: $197-202$

Jamieson NB, Glen P, McMillan DC, McKay CJ, Foulis AK, Carter R, Imrie CW (2005) Systemic inflammatory response predicts outcome in patients undergoing resection for ductal adenocarcinoma head of pancreas. $\mathrm{Br} J$ Cancer 92: $21-23$

Jee SH, Shen SC, Chiu HC, Tsai WL, Kuo ML (2001) Overexpression of interleukin-6 in human basal cell carcinoma cell lines increases anti-apoptotic activity and tumourigenic potency. Oncogene 20: $198-208$

Kinoshita T, Ito H, Miki C (1999) Serum interleukin-6 level reflects the tumour proliferative activity in patients with colorectal carcinoma. Cancer 85: 2526-2531

Kirkegaard T, Edwards J, Tovey S, McGlynn LM, Krishna SN, Mukherjee R, Tam L, Munro AF, Dunne B, Bartlett JM (2006) Observer variation in immunohistochemical analysis of protein expression, time for a change? Histopathology 48: $787-794$

Kotler DP (2000) Cachexia. Ann Intern Med 133: 622-634

Lamb GWA, McMillan DC, Ramsey S, Aitchison M (2006) The relationship between the preoperative systemic inflammatory response and cancerspecific survival in patients undergoing potentially curative resection for renal clear cell cancer. $B r$ J Cancer 94: 781 - 784

Lamm DL (2000) Preventing progression and improving survival with BCG maintenance. Eur Urol 37(S1): 9-15

Maccio A, Lai P, Santona MC, Pagliara L, Melis GB, Mantovani G (1998) High serum levels of soluble IL-2 receptor, cytokines, and $\mathrm{C}$ reactive protein correlate with impairment of $\mathrm{T}$ cell response in patients with advanced epithelial ovarian cancer. Gynecol Oncol 69: 248-252

Maltoni M, Caraceni A, Brunelli C, Broeckaert B, Christakis N, Eychmueller S, Glare P, Nabal M, Vigano A, Larkin P, De Conno F, Hanks G, Kaasa S, Steering Committee of the European Association for Palliative Care
(2005) Prognostic factors in advanced cancer patients: evidence-based clinical recommendations - a study by the Steering Committee of the European Association for Palliative Care. J Clin Oncol 23: 6240-6248

Manoharan M, Soloway MS (2005) Optimal management of the T1G3 bladder cancer. Urol Clin North Am 32: $133-145$

McKeown DJ, Brown DJ, Kelly A, Wallace AM, McMillan DC (2004) The relationship between circulating concentrations of C-reactive protein, inflammatory cytokines and cytokine receptors in patients with non-small-cell lung cancer. Br J Cancer 91: 1993-1995

McMillan DC, Canna K, McArdle CS (2003) Systemic inflammatory response predicts survival following curative resection of colorectal cancer. Br I Surg 90: 215-219

McMillan DC, Scott HR, Watson WS, Preston T, Milroy R, McArdle CS (1998) Longitudinal study of body cell mass depletion and the inflammatory response in cancer patients. Nutr Cancer 31: $101-105$

McNicol AM, Struthers AL, Nolan CE, Hermans J, Haak HR (1997) Proliferation in adrenocortical tumours: correlation with clinical outcome and p53 Status. Endocr Pathol 8: 29-36

O'Donnell MA (2005) Practical applications of intravesical chemotherapy and immunotherapy in high-risk patients with superficial bladder cancer. Urol Clin North Am 32: 121 -131

O'Gorman P, McMillan DC, McArdle CS (2000) Prognostic factors in advanced gastrointestinal cancer patients with weight loss. Nutr Cancer 37: $36-40$

O'Reilly DS, Upton MN, Caslake MJ, Robertson M, Norrie J, McConnachie A, Watt GC, Packard CJ, Midspan and WOSCOPS study groups (2006) Plasma $\mathrm{C}$ reactive protein concentration indicates a direct relation between systemic inflammation and social deprivation. Heart 92: $533-535$

Shariat SF, Matsumoto K, Kim J, Ayala GE, Zhou JH, Jian W, Benedict WF, Lerner SP (2003) Correlation of cyclooxygenase-2 expression with molecular markers, pathological features and clinical outcome of transitional cell carcinoma of the bladder. J Urol 170: 985-989

Shirahama T, Arima J, Akiba S, Sakakura C (2001) Relation between cyclooxygenase-2 expression and tumor invasiveness and patient survival in transitional cell carcinoma of the urinary bladder. Cancer 92: $188-193$

Sobin LH, Wittekind CH (1997) International Union Against Cancer (UICC): TNM Classification of Malignant Tumours. New York: Wiley-Liss

Stavropoulos NE, Ioachim E, Hastazeris K, Goussia A, Agnantis NJ (1998) Lymphocyte subsets in superficial bladder cancer: correlation with biological activity of the tumors. Anticancer Res 18: 2037-2040

Trikha M, Corringham R, Klein B, Rossi JF (2003) Targeted anti-interleukin- 6 monoclonal antibody therapy for cancer: a review of the rationale and clinical evidence. Clin Cancer Res 9: 4653-4665

Vakkila J, Lotze MT (2004) Inflammation and necrosis promote tumour growth. Nat Rev Immunol 4: $641-648$

Witton CJ, Hawe SJ, Cooke TG, Bartlett JM (2004) Cyclooxygenase 2 (COX2) expression is associated with poor outcome in ER-negative, but not ER-positive, breast cancer. Histopathology 45: 47-54 